\title{
The philosophy behind self-managing work teams
}

\author{
Theo $\mathrm{H}$. Veldsman \\ Ernst \& Young, Management Services Limited, P.O. Box 2322, Johannesburg, 2000 Republic of South Africa
}

Received September 1995

\begin{abstract}
In recent times the work team, in contrast to the individual and his/her job, has been propagated as the most appropriate means around which to build the organization of the future. It is hoped that the use of the team as the basic building block of the future organization will release the desired synergy to meet the challenges posed by the new business order. self-managing teams have been proposed as the pinnacle of the team-based organization. The purpose of this article is to discuss the philosophy behind self-managing work teams and indicate how they differ from traditional teams in organizations. Simultaneously an attempt is made to integrate the diverse literature on this concept in a conceptually sound but simple manner.
\end{abstract}

\begin{abstract}
Die filosofie onderliggend aan selfbesturende spanne. Die werkspan word tans, in teenstelling met die individu en sy/ haar pos, voorgestel as die mees toepaslike wyse waarop die organisasie van die toekoms gebou moet word. Daar word gehoop dat die span as basiese bousteen van die toekomstige organisasie die verlangde sinergie sal ontsluit om die uitdagings van die nuwe besigheidsbestel te kan bevredig. Selfbesturende spanne word as die toppunt van die spangebaseerde organisasie beskou. Die doel van die artikel is om die filosofie onderliggend aan selfbesturende spanne te bespreek, en aan te toon hoe hulle van tradisionele spanne in organisasies verskil. Terselfdertyd word gepoog om die uiteenlopende literatuur oor hierdie begrip op ' $n$ teoretiese verdedigbare, maar eenvoudige wyse, te integreer.
\end{abstract}

\section{Introduction}

Sustainable organizational effectiveness requires the successful resolution of the dynamic tension between at least four pairs of opposing poles (e.g. Cohen, 1993; Lawler, 1988; 1992; Mintzberg, 1991; Mohrman, 1993; Quinn \& Cameron, 1988; Rayner, 1993):

- alignment and flexibility;

- differentiation and integration;

- stability and change; and

- control and autonomy.

An overemphasis on one pole of any pair to the detriment of the other results in the positive contribution made by that pole, a strength, inverting to an impediment, or a weakness (Miller, 1990; Quinn, 1990). An overemphasis, for example, on differentiation (or division of labour), leads to overspecialization and work fragmentation. Or over-alignment around a strong culture results in inflexibility and thus little innovation and creativity (Fombrun, 1992). This organizational principle of inversion has been called the 'Icarus paradox' (Miller, 1990) after the Greek story about the boy who flew too close to the sun with self-made wings put together with wax. A significant number of 'excellence' companies (Peters \& Waterman, 1982) have apparently gone the route of strength inversion (Pascale, 1990).

Historically, organizations have been characterized by an overemphasis on the 'left brain' resolution of the above organization dialectic - alignment, differentiation, stability and control - to the detriment of a 'right brain' resolution: flexibility, integration, change and autonomy. The 'left brain' resolution of the organization dialectic may have been successful to some degree in the past in a stable environment. In a world with radically redefined business criteria of speed, quality, cost-effectiveness, innovation and responsiveness (Cohen, 1993; Fisher, 1993; Fombrun, 1992; Galbraith \& Lawler, 1993; Harper \& Harper, 1991; Pasmore, 1994), the positive contribution of the 'left brain' resolution, however, has inverted to become a negative constraint. It is increasingly realized that what is required by organizations is the optimum restoration of the dynamic tension, or rather fusion, between the above-mentioned four pairs of opposing poles in order to successfully meet the newly emerging business criteria (Mintzberg, 1991; Quinn \& Cameron, 1988).

In recent times the work team, in contrast to the individual and his/her job, has been propagated as the most appropriate means around which to build organizations in the search for the balanced resolution of the above-discussed organization dialectic (e.g. Galbraith \& Lawler, 1993; Hoerr, 1989; Lawler, 1992; Lee, 1990; Orsburn et al., 1990; Pasmore, 1994; Rayner, 1993; Walton \& Hackman, 1986; Wellins et al., 1991) through:

- alignment around vision and values, and flexibility around means to achieve the vision and realize the values;

- differentiation around broad areas of specialized competence and integration around measurable, customer focussed whole pieces of work;

- stability around doing the work in a predictable and formalized way and change around continuous improvement and learning; and

- control around expected outcomes and context and autonomy with regards to the actual execution of tasks.

It is hoped that the use of the team as the basic building block of the organization will create the desired synergy to meet the challenge posed by the new world order. This synergy will result from the integrated and flexible application of specialized competence and knowledge focussed on customers; and the direction given by a vision and values in a spiral of continuous improvement so that the performance of the whole is greater than the sum of its parts (Cohen, 1993). Within this context self-managing teams have been proposed as the pinnacle of the team-based organization (Lawler, 1992; Orsburn et al., 1990; Wellins et al., 1991).

The purpose of this article is to discuss the philosophy behind self-managing work teams. The major thrust of the article is to provide an understanding of what self-managing work teams are and how they differ from traditional teams in organizations. Simultaneously an attempt will be made to 
integrate the diverse literature on self-managing teams in a conceptually sound but simple manner. To this end, the following issues are addressed:

- what are the fundamental characteristics of work teams?

- what is a self-managing work team?

- what are the core differentiating dimensions of these teams?

- which conditions foster and support the introduction of this type of team into one's organization?

- what benefits and drawbacks can be expected from these teams?

\section{Fundamental characteristics of work teams}

A team can be defined as a group of persons who are interdependent, interact on a frequent basis with each other and make differential contributions in order to achieve a common goal (Walton \& Hackman, 1986). For the purpose of this discussion, a team can be viewed fundamentally as an open system which converts inputs through transformations into outputs. The conversion process is guided by a common purpose and is embedded within a context. Changes in the conversion process result from feedback from the outputs back to the inputs (Fisher, 1993; Hanna, 1988).

With respect to each of the above team system components a number of basic team actions have to be performed (Gulowsen, 1979; Hackman, 1987; 1992):

- plan: what is to be achieved by when, by whom and with what

- organize: having the right things at the right time and in the right place ready for action

- do: executing the task at hand

- monitor: measuring what is being/has been achieved

- change: improving the way in which things get done

The combination of allocated team actions with the team system components defines the nature of the core team task and thus the boundaries within which the team can and must operate. Table 1 depicts the concept 'core team task' diagrammatically, indicating the combination of team actions and system components. Some examples are given of team activities within the cells. The shaded cells give activities actually performed by the team. The order of the team actions and team system components, as well as the numbers in the cells, depict evolution patterns of increasing team self-management which will be discussed in a later section.

\section{Concept 'self-managing work teams'}

Within the organization a distinction can be drawn between different types of teams in terms of the following categories (Cohen, 1993):

- formal (teams that form an inherent part of the formal organization) versus informal teams ( teams that exist in parallel to the formal organization)

- temporary (teams that exist for a limited period of time) versus permanent teams (teams of relatively long durations)

A self-managing work team is a formal, permanent team. That is, it forms an inherent part of the formal organization and exists for a long duration. Other synonymous terms used for self-managing work teams are: self-directed, autonomous, semi-autonomous, self-leading, self-designing, high performance, high involvement or composite teams (see the references below given with the definition). To a certain measure these different terms reflect theoretical preferences, but more importantly also different levels of evolution that self-managing work teams can move through.

\section{Definition}

A self-managing work team can be defined as a permanent group of 6 to 18 relatively highly skilled organizational members who take a wide ranging and joint responsibility for a whole process/product through the performance of a wide variety of tasks within clearly defined boundaries. Examples

Table 1 Core team task with suggested evolution patterns

TEAM SYSTEM COMPONENTS

\begin{tabular}{|c|c|c|c|c|c|c|c|c|c|c|c|}
\hline \multirow{3}{*}{$\begin{array}{c}\text { TEAM } \\
\text { ACTIONS }\end{array}$} & \multirow[b]{2}{*}{ CHANGE } & \multicolumn{2}{|c|}{ TRANSFORMATION } & \multicolumn{2}{|c|}{ FEEDBACK } & \multicolumn{2}{|c|}{ OUTPUTS } & \multicolumn{2}{|c|}{ INPUTS } & \multicolumn{2}{|c|}{ CONTEXT } \\
\hline & & - Process & 5 & $\begin{array}{l}\text { - Redesign } \\
\text { sampling and } \\
\text { analysis } \\
\text { approach }\end{array}$ & 6 & $?$ & & $?$ & & $?$ & \\
\hline & PLAN & - Coal sctting & 4 & $\begin{array}{l}\text { - Sampling and } \\
\text { analysis }\end{array}$ & 5 & $\begin{array}{l}\text { - Customer } \\
\text { contact plan }\end{array}$ & 6 & - Stock plan & 7 & $?$ & \\
\hline & ORGANISE & $\begin{array}{l}\text { - Work } \\
\text { allocention } \\
\text { - Production } \\
\text { schoduting }\end{array}$ & 3 & $\begin{array}{l}\text { - Sampling and } \\
\text { analysis } \\
\text { schedule }\end{array}$ & 4 & $\begin{array}{l}\text { - Customer } \\
\text { contact } \\
\text { schedule }\end{array}$ & 5 & $\begin{array}{l}\text { - Stock } \\
\text { ordering } \\
\text { schaduk }\end{array}$ & 6 & $?$ & \\
\hline & MONITOR & $\begin{array}{l}\text { - Quality of } \\
\text { outpart } \\
\text { - Quntity of } \\
\text { - Retput } \\
\text { - Record keepi }\end{array}$ & 2 & - Analysis & 3 & $\begin{array}{l}\text { - Sales } \\
\text { - Customer } \\
\text { satisfaction } \\
\text { reports } \\
\text { - Stock contr }\end{array}$ & 4 & - Stock control & 5 & $\begin{array}{l}\text { - Monitoring } \\
\text { of events in } \\
\text { organisation }\end{array}$ & 6 \\
\hline & DO & $\begin{array}{l}\text { - Production } \\
\text { - Maintenance }\end{array}$ & 1 & - Sampling & 2 & $\begin{array}{l}\text { - Cuatomer } \\
\text { contact }\end{array}$ & 3 & $\begin{array}{l}\text { - Linison with } \\
\text { internal } \\
\text { supplier }\end{array}$ & 4 & $\begin{array}{l}\text { Contribution } \\
\text { to other } \\
\text { teams in } \\
\text { Organisation }\end{array}$ & 5 \\
\hline
\end{tabular}


of a whole product/process are the production of a complete product or a complete sub-assembly; a fully processed insurance claim or the provision of a one stop service to customers (Cohen, 1993; Fisher, 1993; Glaser, 1992; Harper \& Harper, 1991; Hoerr, 1989; Lawler, 1992; Lee, 1990; Mohrman, 1993; Orsburn et al., 1990; Pearce \& Ravlin, 1987; Raubenheimer, 1990; Walton \& Heckman, 1986; Wellins et al., 1991). The essence of self-managing work teams is contained in the words 'wide ranging responsibility' and 'whole process/product' which will be explored in further sections of the article.

\section{Premises underlying self-managing work teams}

Self-managing work teams rest on four premises (Wellins et al., 1991):

- those who are closest to the work know best how to perform and improve the work;

- most employees want to feel they 'own' their work and are making meaningful contributions to the effectiveness of their organizations;

- teams provide possibilities for empowerment and enablement not available to individual employees locked up in 'stand alone' jobs; and

- giving the team a 'whole job (or task)' to do.

\section{Origin of the concept 'self-managing work teams'}

The concept of self-managing work teams originated in a theoretical perspective entitled socio-technical system theory. The socio-technical system approach was developed by Eric Trist and his colleagues at the Tavistock Institute, Britain, from the 1950s onwards. According to this approach the essence of organizational effectiveness is the joint optimization of the technical (or technology and its resulting work flow) and social (or people) requirements of a work system, such as an organization. Joint optimization is required in order to create a work system that is both productive and humanly satisfying. Joint optimization can only be achieved by focussing on the design of an intact work system where such a system would consist of an integrated, mutually supportive and interdependent set of activities making up a 'whole job'. This whole job must be given to a team to perform. The emphasis is therefore on matching whole jobs to intact teams and vice versa in order to attain joint optimization and thus organizational effectiveness (Cherns, 1987; Cummings, 1978; Fisher, 1993; Pasmore, 1988; Pearce \& Ravlin, 1987; Raubenheimer, 1990).

The socio-technical system with its commensurate concept of self-managing work teams spread from Britain in the 1950s, firstly to the Scandinavian countries, and thereafter to the United States of America where it is now regarded as the wave of the future in making organizations more effective and satisfying work places.

\section{Core differentiating dimensions of self-managing work teams}

The essential, differentiating nature of self-managing work teams is locked up in the following key issue: what degree of responsibility will a team be given to perform the various team actions (e.g. plan, organize) relative to the respective team system components (e.g. transformation, inputs)? Put differently: what is the nature of the core team task and the autonomy the team has with respect to this task?

The degree of responsibility pertains to the level of involvement expected of organizational members. The scope of core team task delineates the extent of empowerment and enabling that must occur in the team. In turn, the expected level of involvement and scope of the core team task affect the nature of the leadership required around and within the team. The core differentiating dimensions of self-managing work teams thus are contained in the following dynamically, interrelated concepts: involvement, empowerment, enabling and leadership. The dynamic and unfolding interrelationship between these concepts provides a fifth concept, the concept of evolution: evolving levels of involvement, empowerment, enabling and leadership (Cohen, 1993; Fisher, 1993; Glaser, 1992; Harper \& Harper, 1991; Hoerr, 1989; Lawler, 1992; Lee, 1990; Mohrman, 1993; Orsburn et al., 1990; Pearce \& Ravlin, 1987; Raubenheimer, 1990; Walton \& Hackman, 1986; Wellins et al., 1991).

Succinctly put, the essential difference between self-managing work teams and traditional teams is contained in a dynamic process of continuous evolution towards increasingly higher levels of involvement, empowerment, enabling and leadership. Redefined in terms of the above-mentioned key team issue: a progressively increasing level of team responsibility with respect to a constantly expanding core team task. In this respect self-managing work teams are a concrete manifestation of the 'learning' organization (Pedler et al., 1991; Rosow \& Zager, 1998; Senge, 1990). Each of the core differentiating dimensions will be discussed in turn.

\section{Involvement}

Involvement can be described as the freedom awarded to organizational members to take independent action. It thus refers to 'having control over and/or having a say in' (Glaser, 1990; Heckman, 1987; Lawler, 1986; Lawler et al., 1989; Tjosvold, 1987). Involvement pertains to a way of doing things within a circumscribed area of work as a function of a given distribution of responsibility between the superior and his/her subordinates.

A continuum of involvement can be discerned (see Figure 1 below) running from a high degree of responsibility awarded to the superior relative to his/her subordinates (low involvement: 'we only work here') to a high degree of responsibility awarded to subordinates relative to their superior (high involvement: 'we have full say in matters of concern to us').

Five levels of involvement can be distinguished along the continuum given in Figure 1, moving from low to high involvement (Lawler, 1986; Margulies \& Black, 1987; Orsburn et al., 1990; Tjosvold, 1987):

- involvement through informing (low involvement): superiors have complete responsibility for their subordinates' area of work, make all decisions and merely inform his/ her subordinates accordingly.

- involvement through consultation (some to reasonable involvement): superiors make the decisions, but invite comments from their subordinates on such decisions. Or subordinates have the opportunity to offer suggestions on matters of concern to them but the superior retains the discretion to accept or reject such suggestions. 
- involvement through co-determination (equal involvement): the superior and his/her subordinates jointly make decisions.

- involvement through self-management (high involvement): subordinates have a full say in matters within their area of work but within policy/procedural guidelines laid down by their superior.

- involvement through self-government (full or complete involvement): subordinates virtually have a complete say in all respects within their area of work, as well as the context of their work, and are free to make decisions in whatever way they wish.

In the case of a self-managing work team, the level of involvement by the team in the core team task can vary between co-determination as a minimum level up to self-government as the maximum. Otherwise the team cannot be said to be a self-managing work team. The scope of the core team task may be wider or narrower depending on the extent of empowerment and enabling around which the task has been constructed and the level of evolution of this task. This issue will be further explored in the next section. In the case of the context in which this core team task is embedded, the level of involvement by the self-managing work team can vary between informing as the minimum level and co-determination as the maximum.

As a minimum precondition self-managing work teams require a relatively high degree of self-management with respect to a major portion of the core task team. From that basis the level of involvement can increase as the team matures to handle a higher level of involvement for a given portion of the team task. Traditional teams are given little direct involverment in matters of concern to them within their area of work. At most their expected level of involvement is that of consultation with respect to a very narrowly defined core team task. Usually the core team task is so narrowly defined that it is non-existent as a team task for practical purposes and

WORK AREA OF SUBORDINATES

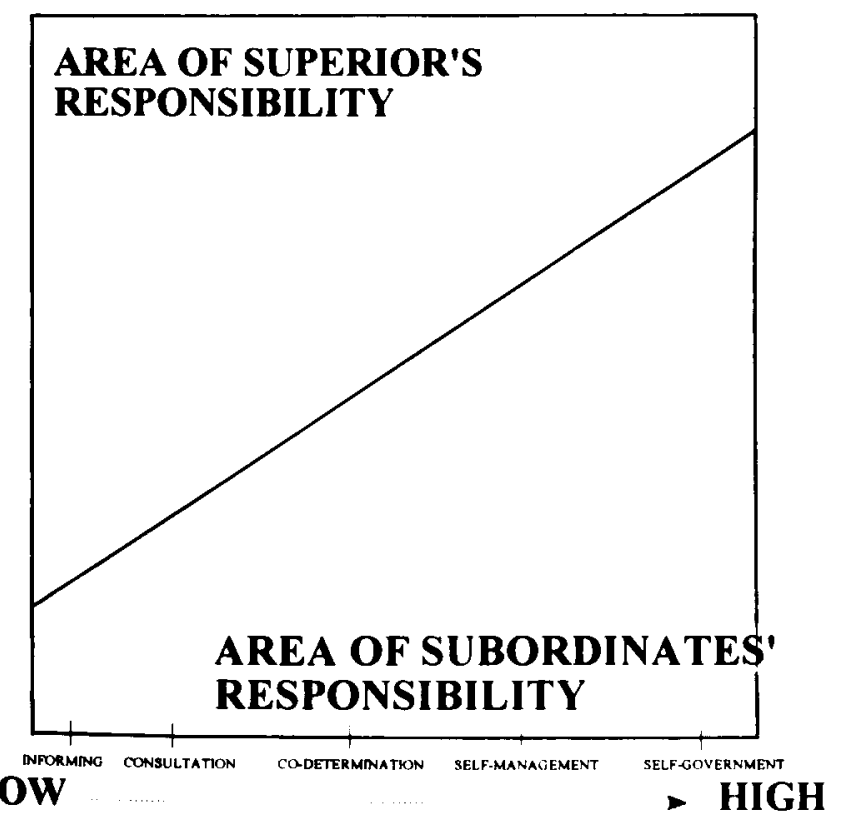

INVOLVEMENT

Figure 1 Involvement as a function of a given distribution of responsibility rather takes on the nature of an individually performed task where this task under most conditions does not even form a whole job.

Involvement thus must be an inherent part of the organization's people philosophy if self-managing work teams are to be successful (Fisher, 1993; Glaser, 1990; Heckman, 1987; 1992; Harper \& Harper, 1992; Lawler, 1992; 1993; Orsburn et al., 1990).

\section{Empowerment}

Empowerment refers to the scope of the core team task. As defined above, involvement pertains to the freedom to act. Empower entails with respect to what the team can exercise this freedom, where the 'what' encompasses the scope of the core team task.

A distinction can be drawn between the potential and actual core team task. The potential core team task entails the full range of team components and actions that may be included in the team's scope of work. The actual core team task refers to the scope of work given to and performed by the team, that is its empowerment. The difference between the potential and actual core team tasks circumscribes the work still being performed by the team's superior (or someone else outside the team) as part of his/her responsibility for the total team core task. The gap between the potential and actual core team indicates one dimension of the growth potential available to the team, the other dimension being an increase in the level of involvement as described above.

Important when defining the scope of the core team task is to give a team empowerment with respect to intact (that is non fragmented) basic team actions and team system components. The inherent integrity of actions and components must be maintained in order to create 'whole jobs'. Only in this way can clear responsibilities and accountabilities be awarded, meaningful and satisfying work be created, and a sense of ownership be established (Lawler, 1992).

The scope of the core team task can be three-dimensionally circumscribed (see Table 1):

- vertically: the number of team system components to be handled by the team: transformation, inputs, outputs, feedback and/or context

- horizontally: the range of basic actions the team must perform for each of the team system components: plan, organize, do, monitor, and/or change

- laterally: the types of tasks team members must be able to perform with respect to a team system component and its associated basic action(s), e.g. production, maintenance, quality assurance, housekeeping, human resource. Important here is also the level of complexity at which these tasks must be performed: basic, intermediate or advanced. The lateral dimension therefore encompasses the level of multi-skilling and multi-tasking that have to occur within the team.

According to Table 1 the scope of the core team task in this example (the shaded area) revolves mainly around the transformation component, covering all five team action categories. Some actions, however, are also included with respect to inputs, outputs and feedback. The range of task types within the cells is wide, particularly the transformation component. The unshaded cells in Table 1 indicate elements of the core 
team task that are currently being performed by someone else, e.g. the team's supervisor. With respect to each team system component, team action and the associated task types, a desired level of involvement would have to be defined.

For the scope of core team task depicted in Table 1 one would expect the team to be self-managing on transformation (organize, do, monitor) and feedback (monitor). In the case of transformation (plan, change), inputs (do, monitor) and outputs (do) the level of expected involvement could be co-determination. The level of involvement has to be agreed upon between the team and management. Representatives of unions could also form part of this negotiation.

Table 1, however, demonstrates a static picture. What needs to be done in order to engender a learning organization, is to fill all the cells of Table 1 with the full and complete set of tasks that have to be performed within an area of work across all system components and basic action categories. From this potential core team task phases of evolution can be constructed through which teams can move as they mature. That is, the actualization of the potential core team task through time.

The phases of evolution would consist of logical combinations of team system components and basic team actions, that is 'whole' jobs. Related to each evolutionary phase would also be changes in the expected level of involvement, reflecting the increasing downloading of responsibility onto the team as it develops the competence to take on higher levels of responsibility. The essence of this continuous evolution process is thus a constant redefinition of the scope of the actual core team task, and the levels of involvement that the team has relative to that core task. No wonder that self-directing teams are regarded in some quarters as the highest form of the learning organization (Fisher, 1993; Rosow \& Zager, 1988). The different terms used for self-managing work teams in some measure attempt to indicate these increasing levels of empowerment and involvement, particularly the terms: superior led team $\rightarrow$ self-managing $\rightarrow$ self-designing (e.g. Hackman, 1987; 1992), the arrows indicating the evolution phases.

A key question is whether typical patterns of evolution can be discerned. Theoretically it appears as if such patterns do exist, although the literature on self-managing work teams does not pay a lot of attention to the definition of evolutionary phases. The principle of evolution is mostly only stated and left at that. Table 1 provides a suggested way of distinguishing patterns of evolution. The disadvantage of this table is that it presents in a static way a dynamic concept. A similar number in a cell (or across cells) indicate the cell(s) making up the scope of core team task for a given level of evolution. The phases of evolution run from 1, bring Phase I to 7 being Phase VII. As the evolution proceeds from Phase I to Phase VII the scope of the actual core team task of a later phase would be incorporated into the earlier phases' scope.

The order of the team system components and basic action categories in Table 1 have been arranged so as to reflect a coherent order of evolution in terms of the principles of increasing complexity and level of direct concern to the team regarding the team system components and basic team actions. E.g. 'doing die transformation' is relatively less complex and of more direct concern to the team than 'planning inputs' (See Table 1).
According to Table 1 it is proposed that the scope of the core team task can evolve as follows:

Phase I Transformation (Do) (1)

Phase II Transformation (Do, Monitor); Feedback (Do) $(1+2)$

Phase III Transformation (Do, Monitor, Organize); Feedback (Do, Monitor); Outputs (Do) $(1+2+3)$

Etc.

Further research would be required to test the hypothetical patterns of evolution suggested in Table 1. Important to note with respect to Table 1 are those basic action categories relative to outputs, inputs and context that probably would only become part of the core team task under exceptional circumstances: Outputs (change); Inputs (change); and Context (Organize, Plan, Change). To the best of the author's knowledge all of the literature on self-managing work teams would support this view. The major responsibility for these excluded areas would virtually almost remain with the superior except if the level of involvement across the whole core team task becomes one of self-government.

Apart from the evolutionary phases with respect to core team task, the level of expected involvement for a current phase's scope of core team task could increase as it gets incorporated into a next phase's scope. E.g, Phase I: Transformation (Do) could move from co-determination to selfmanagement as and when this phase is subsumed under Phase II. As Phase II in turn gets incorporated into Phase III, Transformation (Do) could move to self-government.

Work teams also go through life cycles of development. E.g. orientation, differentiation, integration, maturity (Raubenheimer, 1990) or start-up, state of confusion, leader-centred, tightly formed, self-managing (Harper \& Harper, 1991; Orsburn et al., 1990). It could be expected that as the team enters a higher phase of evolution, that is a redefined scope of core team task, that it would also enter a rejuvenated life cycle. The implication of this dynamic is that a higher stage of evolution, which means increased empowerment and involvement, can only be introduced once a team has stabilized and reached the latter stages of its life cycle with respect to that core team task.

\section{Enabling}

Simultaneously to the demarcation of empowerment, the level of expected enabling must also be established. Enabling refers to the repertoire of competencies and behaviours individual team members must have and manifest with respect to a core team task. Enabling and empowerment thus must be kept congruent at all times in order to create the necessary performance potential. The number of team members with particular repertoires must also be established. Namely, the desired skills densities within the team. Enabling thus covers two aspects: individual skills repertoires and the densities of such repertoires across the whole team (e.g. Veldsman, 1991).

In traditional teams the scope of the core team task, that is the degree of empowerment, is vertically, horizontally and laterally very narrow. Further more, the expected level of desired involvement typically does not exceed co-determination. In terms of enabling organizational members have very limited skills repertoires, usually a single skill, and very low 
skills densities exist, usually only one to two persons have a given skill within an area of work.

\section{Leadership}

Within the context of this discussion, leadership can be defined as those activities that contribute towards the establishment and maintenance of favourable team performance conditions relative to the given core team task (Cummings, 1978; Fisher, 1993; Hackman, 1992; Hackman \& Walton, 1986; Lawler, 1992; Pasmore, 1988; Wellins et al., 1991).

It is proposed that for the purpose of this discussion a distinction can be drawn between leadership functions and dimensions. 'Functions' can be seen as analogous to the basic team actions. 'Dimensions' are similar in conception to the team system components.

At least the following leadership functions can be identified:

- do: executing a particular leadership task.

- coach, facilitate and advise: helping and assisting others to perform a task.

- (re)design and build: generating support systems, e.g. a manpower planning system or a interface, through which a task can be executed in a standardized and formalized way.

- link and mediate: liaisoning with stakeholders and key role players at the team-context interface.

- envision: building and communicating a desired future state, and mobilizing people around that state.

Two broad leadership dimensions can be distinguished:

- enabling: building desired competencies and behaviours in people, and ensuring their utilization.

- empowerment: enhancing the probability of team success through the reduction of core team task uncertainty (internal empowerment) and the reduction of contextual uncertainty (external empowerment).

These functions and dimensions create the conditions for team effectiveness (Hackman \& Walton, 1986).
Table 2 provides examples of specific leadership tasks (or roles) within the context of the leadership functions and dimensions.

Similar to the core team task, patterns of evolution can be proposed with respect to the leadership tasks given in Table 2 as depicted in the aforementioned table. These suggested patterns have to be researched further. (The same convention is used to indicate phases as in Table 1.) The order of the leadership actions and dimensions again have been arranged so as to reflect a coherent order of evolution for the same reasons as in the case of the team system components and basic action categories.

Related to each evolutionary phase could also be changes in the expected level of involvement with respect to leadership tasks. The level of involvement again could change as an earlier phase is incorporated into a later phase. In the case of self-managing work teams the level of involvement typically would vary between informing and self-managing.

According to Table 2 it is proposed that the leadership tasks of the team can evolve as follows:

Phase I Enabling (Do) (1)

Phase II Internal empowerment (Do); Enabling (Do, Link and mediate) $(1+2)$.

It also appears as if some leadership tasks normally would not be evolved to the team, namely External Empowerment (Link and Mediate; Envision) and Internal Empowerment (Envision).

As the level of involvement increases from co-determination upwards for a particular leadership task, the location of leadership shifts from external leadership (namely leadership outside of the team), exercised by a formally designated person, to within-team leadership for that leadership task. The within-in team leadership can be resident in a team member or be a part of a rotating portfolio amongst team members. As the team achieves higher levels of maturity, the tendency is towards a rotating portfolio.

Within traditional teams the leadership tasks are firmly located and locked into an externally located and formally designated person where the level of involvement typically at most would be consultation.

Table 2 Leadership task matrix with proposed patterns of evolution

\begin{tabular}{|c|c|c|c|c|c|c|c|c|c|c|c|}
\hline \multicolumn{2}{|c|}{ Leadership Functions } & \multicolumn{2}{|l|}{ DO } & \multicolumn{2}{|c|}{$\begin{array}{l}\text { (RE) DESIGN } \\
\text { AND BUILD }\end{array}$} & \multicolumn{2}{|c|}{$\begin{array}{c}\text { COACH, } \\
\text { FACILITATE, } \\
\text { HELP }\end{array}$} & \multicolumn{2}{|c|}{$\begin{array}{l}\text { LINK AND } \\
\text { MEDIATE }\end{array}$} & \multicolumn{2}{|c|}{ ENVISION } \\
\hline \multirow{3}{*}{$\begin{array}{c}\text { LEA- } \\
\text { DER- } \\
\text { SHIP } \\
\text { DI- } \\
\text { MEN- } \\
\text { SIONS }\end{array}$} & $\begin{array}{l}\text { EXTERNAL } \\
\text { EMPOWERMENT } \\
\text { (CONTEXT } \\
\text { UNCERTANTY) }\end{array}$ & $\begin{array}{l}\text { - Across organi- } \\
\text { sational colla- } \\
\text { boration } \\
\text { - Rapport } \\
\text { building }\end{array}$ & 3 & $\begin{array}{l}\text { - Customer } \\
\text { interface } \\
\text { design }\end{array}$ & 4 & $\begin{array}{l}\text { Coaching on } \\
\text { liaison roles } \\
\text { fulfilled by } \\
\text { team } \\
\text { members }\end{array}$ & 5 & $\begin{array}{l}\text { - Modiation } \\
\text { - Attitration } \\
\text { - Customer / } \\
\text { Supplier } \\
\text { advocacy }\end{array}$ & 2 & $\begin{array}{l}\text { - Mistion } \\
\text { and vision } \\
\text { translation } \\
\text { and comm } \\
\text { nication } \\
\text { - Role mode }\end{array}$ & $?$ \\
\hline & $\begin{array}{l}\text { INTERNAL } \\
\text { EMPOWERMENT } \\
\text { (TASK } \\
\text { UNCERTAINTY }\end{array}$ & $\begin{array}{l}\text { - Goal setting } \\
\text { - Standard } \\
\text { Setting }\end{array}$ & 2 & $\begin{array}{l}\text { - Work } \\
\text { process } \\
\text { architecture } \\
\text { - Infra- } \\
\text { structure } \\
\text { building }\end{array}$ & 3 & $\begin{array}{l}\text { - Performance } \\
\text { enhancement } \\
\text { - Trouble } \\
\text { shooting } \\
\text { - Problem } \\
\text { solving } \\
\text { - Conflict reso }\end{array}$ & 4 & $\begin{array}{l}\text { - Resource } \\
\text { acquisition }\end{array}$ & 5 & $\begin{array}{l}\text { - Core team } \\
\text { task } \\
\text { definition }\end{array}$ & $?$ \\
\hline & ENABLING & $\begin{array}{l}\text { - Team member } \\
\text { development }\end{array}$ & 1 & $\begin{array}{l}\text { Design of } \\
\text { manpower } \\
\text { planning } \\
\text { system }\end{array}$ & 2 & $\begin{array}{l}\text { - Guidance on } \\
\text { team } \\
\text { development }\end{array}$ & 3 & $\begin{array}{l}\text { - Provision } \\
\text { of T \& D } \\
\text { resources }\end{array}$ & 4 & $\begin{array}{l}\text { - Setting of } \\
\text { T \& D } \\
\text { prioritics. }\end{array}$ & 5 \\
\hline
\end{tabular}


In summary, what then are the core distinguishing dimensions of self-managing work teams when compared to traditional teams? As discussed above, the answer is contained in the terms 'involvement', 'empowerment', 'enabling', 'evolution' and 'leadership'. Put differently, in the continuous redefinition of the core task team and the relocation of leadership tasks as the team matures to take on increasing levels of responsibility. Within traditional teams little involvement, empowerment, enabling and evolution occur. Leadership remains with little exception externally located relative to the team.

\section{Conditions that foster and support the introduction of self-managing work teams}

The introduction of self-managing teams will have a significant impact on the organization's mode of operation and its underlying operating philosophy. The implementation thus must be approached as a larger scale organizational change process and managed as such. Experience with self-managing work teams shows a $50 \%$ failure rate (Fisher, 1993). Organizations wishing to introduce these teams therefore must ensure that conducive conditions exist within their organizations to enhance the probability of a successful introduction and sustaining of such teams. Conducive conditions exist if the positive forces for change outweigh the negative forces. Unfavourable conditions are present if the inverse relationship holds.

\section{Types of forces}

In weighing up the positive and negative forces at least the following types of forces must be considered (Cohen, 1993; Cummings, 1978; Fisher, 1993; Hackman, 1992; Harper \& Harper, 1991; Lawler, 1992; Lee, 1990; Orsburn et al., 1990; Pearce \& Ravlin, 1987; Wellins et al., 1991):

- environmenal: does a strategic justification for the intervention exist? Have a mandate and vision been formulated and thoroughly communicated to all stakeholders? Is the organization's market healthy or promising enough to support the expected productivity gains through the teams without a reduction in the organization's work force?

- stakeholders: do management and supervisors support increasing levels of involvement and are they willing to learn and use high involvement approaches? Is management willing to commit the necessary resources and make the required investment to transform the organization? Is there sufficient commitment by management to sustain the intervention for the expected period of implementation (three to five years)? Is management willing to offer certain minimum assurances to put a 'safety net' underneath the intervention? Are employees able and willing to move to higher levels of responsibility, empowerment and enabling? Are employee representative associations agreeable to renegotiate existing job responsibilities and scopes of work?

- organizational: do organizational policies, architecture (that is organic) and culture support the philosophy of self-managing work team? If not, is there a willingness and ability to change and make them congruent? Does the nature of the organization's work processes lend themselves to team work? Do the work processes have the po- tential for motivated and committed organizational members to improve performance significantly? Is exper. tise on large scale organizational change available in the organization? Are the necessary resources required for the introduction of these teams available in the organization? Is sufficient knowledge about self-managing work teams present in the organization?

- outcomes: does agreement exist within the organization regarding the expected gains and are these expectations realistic? Will the expected gains brought about by selfmanaging teams outweigh the expected costs? Is it understood and accepted that the introduction of these teams will initially result in a drop in performance?

\section{Lessons learnt}

What have been some of the lessons learnt regarding the introduction of self-managing teams into organizations? Applying these lessons may also enhance the probability of success. Some of the more important lessons are:

- top level commitment (Fisher, 1993; Harper \& Harper, 1991; Orsburn et al., 1990)

- management-employee trust (Orsburn et al., 1990)

- the willingness to take risks and experiment (Orsburn et al., 1990)

- sufficient time, resources and patience (Harper \& Harper, 1991; Orsburn et al., 1990)

- a high investment in training (Orsburn et al., 1990)

- the provision of both hard and soft skills to teams, that is technical, interpersonal and team skills (Harper \& Harper, 1991; Lawler, 1992; Orsburn et al., 1990)

- union participation (Harper \& Harper, 1991; Orsburn et al., 1990)

- the creation of one's own version (Harper \& Harper, 1991)

- maintaining the right momentum (Harper \& Harper, 1991)

- minimal critical specification, that is do not overdesign the teams (Cherns, 1987; Fisher, 1993; Wellins et al., 1991)

- basing the design of the teams upon socio-technical and work process principles (Cherns, 1987; Cummings, 1978; Pasmore, 1988)

- a willingness to accept help (Wellins et al., 1991)

- perseverance and persistence: if one starts, one must finish as well (Wellins et al., 1991)

- the provision of assurances (Harper \& Harper, 1991)

- the provision of the necessary limits to the design (Wellins et al., 1991).

\section{Expected benefits and drawbacks of self-managing work teams}

\section{Benefits}

The expected benefits from self-managing work teams can be divided into two broad categories:

- more efficient operations

- improved outcomes

Table 3 provides a summary of some of the major benefits associated with these two categories. 
Table 3 Benefits associated with self-managing work teams

\begin{tabular}{|c|c|}
\hline & Spec \\
\hline erations & $\begin{array}{l}\text { - } 50-75 \% \text { reduction in processing/work cycle time } \\
\text { (Orsburn et al., 1990) } \\
\text { - Increased capacity to act/faster response to change } \\
\text { (Harper \& Harper, } 1991 \text {; Wellins et al., 1991) } \\
\text { - Streamlining of work processes (Harper \& Harper, 1991; } \\
\text { Orsburn et al., 1990) } \\
\text { - Safety improvements (15 to 20\%)(Rayner, 1993) } \\
\text { - Increased flexibility in the utilization of resources } \\
\text { (Orsburn et al., 1990; Wellins et al., 1991) } \\
\text { - Significant reduction in change-over times (Orsburn } \\
\text { et al., 1990) } \\
\text { - Reduced time to market (50-60\%) (Rayner, 1993) } \\
\text { - Greater self-reliance and resourcefulness (Fisher, 1993) } \\
\text { - Constant growth and fuller utilization of people's } \\
\text { potential (Harper \& Harper, 1991) } \\
\text { - Continuous improvement (Harper \& Harper, 1991) } \\
\text { - Fiatter and leaner organization (Cohen, 1993; Harper \& } \\
\text { Harper, 1991; Lawler, 1992; Orsburn et al., 1990; } \\
\text { Wellins et al., 1991) }\end{array}$ \\
\hline $\begin{array}{l}\text { Improved } \\
\text { outcomes }\end{array}$ & $\begin{array}{l}\text { Organizational } \\
\text { - Significant productivity improvements (on average } \\
30 \% \text { to 40\%) (Cohen, 1993; Glaser, 1990; Harper \& } \\
\text { Harper, 1991; Lawler, 1992; Lee, 1990; Orsburn } \\
\text { et al. 1990; Rayner, 1993; Wellins et al., 1991) } \\
\text { - Reduced operating costs (30\% to 50\%) (Fisher, 1993; } \\
\text { Pearce \& Ravlin, 1987; Rayner, 1993; Wellins et al., 1991) } \\
\text { - Improved quality (Cohen, 1993; Fisher, 1993; Harper \& } \\
\text { Harper, 1991; Hoerr, 1989; Lawler, 1992; Orsburn et al., } \\
\text { 1990; Rayner, 1993; Wellins et al., 1991) } \\
\text { - Increased customer satisfaction (Cohen. 1993; Fisher, } \\
\text { 1993; Harper \& Harper, 1991; Orsburn et al., 1990) } \\
\text { People } \\
\text { - Increased commitment to organizational goals (Orsburn } \\
\text { et al., 1990) } \\
\text { - Improved quality of work life (15 to 40\%) (Rayner, 1993) } \\
\text { - Greater sense of belonging and satisfaction (Fisher, 1993; } \\
\text { Harper \& Harper, 1991; Pearce \& Ravlin, 1987; } \\
\text { Wellins et al., 1991) } \\
\text { - Reduced absenteeism and turnover (Harper \& Harper. 1991) }\end{array}$ \\
\hline
\end{tabular}

\section{Drawbacks}

The drawbacks of self-managing work teams center primarily around factors such as:

- the high investment to introduce these teams into one's organization.

- the long time period before they become fully institutionalized.

- the need for significant changes in the organization's policies, architecture and culture to sustain and support these teams.

- the high probability of failure.

- the upper limit placed on their evolution by team and organization members' ability and education.

- the continued pressure by teams for further upward evolution which may place the initial team mandate under pressure. If there is an unwillingness to change this mandate, the invention itself may become at risk.

- the high degree of change management skills required to introduce the team successfully.

\section{Conclusion}

The basic requirement in future to build organizations around teams is generally accepted. Inter alia this requirement has been invoked by the need to resolve the organization dialectic of alignment-flexibility; differentiation-integration; stabilitychange and control-involvement in a balanced fashion. The purpose of this article has been to discuss the philosophy behind self-managing work teams as the highest form of team work in organizations. It was indicated that the crux of these teams are contained in the concepts of involvement, empowerment, enabling, leadership and evolution. Conditions that foster and support the introduction of self-managing work teams were also discussed, as well as the benefits and drawbacks of these teams.

\section{References}

Cherns, A. 1987. 'Principles of socio-technical design revisited', Human Relations, Vol. 40: 153-162.

Cohen, S.G. 1993. 'New approaches to teams and teamwork'. In Galbraith, J.R \& Lawler, E.E (Eds.). Organising for the future. The new logic for managing complex organisations. San Francisco: Jossey-Bass, pp. 194-226.

Cummings, T.G. 1978. 'Self-regulating work groups: a socio-technical synthesis', Academy of Management Review, Vol. 3: 625-634.

Fisher, K. 1993. Leading self-directed work teams. New York: McGraw-Hill.

Fombrun, C.J. 1992. Turning points. New York: McGraw-Hill Galbraith, J.R. \& Lawler, E.E. 1993. 'Challenges to the established order'. In Galbraith, J.R. \& Lawler, E.E. (Eds.). Organising for the future. The new logic for managing complex organizations. San Francisco: Jossey-Bass, pp.109-141.

Glaser, R. (Ed.) 1992. Classic readings in selj managing teamwork. King of Prussia, USA: Organization Design and Development.

Glaser, R. 1990. Moving your team towards self-management. King of Prussia, USA: Organization Design and Development.

Gulowsen, J.A. 1979. 'A measure of work group autonomy'. In Davis, L. \& Taylor, J. (Eds.). Design of jobs. Santa Monica: Goodyear.

Hackman, J.R. 1987. 'The design of work teams'. In Lorsch, J.W (Ed.). Handbook of organisational behaviour. Englewood Cliffs: Prentice-Hall, pp.315-342.

Hackman, J.R. 1992. 'The psychology of self-management in organizations'. In Glaser, R. (Ed.). Classic readings in self-managing teamwork. King of Prussia: Organization Design \& Development, pp.143-193

Hackman, J.R. \& Walton, R.E. 1986. Leading groups in organizations. In Goodman, P.S. \& Associates. Designing effective work groups. San Francisco: Jossey-Bass, pp. $72-119$

Hanna. D.P. 1988. Designing organisations for high performance. Reading, Mass.: Addison-Wesley.

Harper, B. \& Harper, A. 1991. Succeeding as a self-directed work team. Croton-on-Hudson: MW Corporation. 
Hoerr. 3. 1989. 'The payoff from teamwork'. Business Week. 10 July: $36-42$

Lawler. E.E. 1986. High imolvement management. San Francisco Jossey-Bass

Lawler. E.E. 1988. Transformat on from control to involvement. In Kilmann. R.H.. Covin. T.J and Associates. Corporale iransforma. tion San Francisco: Jossey-Bass. pp $46-65$

Lawler. E.E. 1992. The ultimate advandage. Creating the high involvement organisation. San Francisco: Jossey-Bass.

Lawler. E.E. 1993. 'Creating the higb-involvement organisation'. In Galbrath. J.R. \& Lawler. E.E. (Eds.). Organising for the future. The new logic for managing complex organisations. San Francisco: Jossey-Bass. pp.172-193.

Lawler. E.E., Ledford. G.E \& Mohrman. S.A. 1989. Employee involvement in America: a study of contemporary practice. Houston: Amencan Producuvity and Quality Centre.

Lee. C. 1990) 'Beyond team work'. Training. June: 25-32.

Margulues. N. \& Black. S. 1987. 'Perspectives on the implementatron of partucipatuve approaches'. Human Resources Management, Vol. 26: $385-412$.

Muller. D. 1990. The Icarus paradox. How successful companies bring about their own downfall. New York: Harper.

Mintzberg, H. 1991. 'The effective organization: forces and forms', Sloan Management Review, Winter. 54-67.

Mohrman. S.A. 1993. 'Integrating roles and structure in the lateral organization'. In Galbraith. J.R. \& Lawler, E.E. (Eds.). Organising for the future. The new logic for managing complex organizations. San Francisco: Jossey-Bass, pp.109-141.

Orsburn, J.D.. Moran. L.. Musselwhite, E., Zenger, J.H. \& Perrin, C. 1990. Self-directed work teams. The new American challenge. Homewood: Business One Irwin.

Pascale, R.T. 1990. Managing on the edge. New York: Simon \& Schuster.

Pasmore, W.A. 1988. Designing effective organizations. The sociotechnical systems perspective. New York: John Wiley \& Sons.

Pasmore, W.A. 1994. Creating strategic change. Designing the flexi- ble, high-performaning organization. New York: John Wiley \& Sons.

Pearce. J.A \& Ravlın. E.C. 1987. 'The design and activation of selfregulating work groups'. Human Relations. Vol. 40: 751-782.

Pedlet. M.. Burgoyne. J. \& Boydell. T. 1991. The learning company. New York: McGraw- Hill.

Peters, T.J. \& Waterman, R.H. 1982. In search of excellence. New York: Harper \& Row.

Quinn. R.E. 1990. Beyond rational management. Mastering the paradoxes and competing demands of high performance. San Francisco: Jossey-Bass

Quinn, R.E. \& Cameron, K.S. 1988. Paradox and transformation. Toward a theory of change in organisation and management. Cambridge. Mass: Ballinger.

Raubenheimer, I. van W. 1990 . Autonomous work groups. A review of the literature. Johannesburg: Chamber of Mines Research Organisation

Rosow, J.M. \& Zager, R. 1988. Training - the competitive edge. San Francisco: Jossey-Bass.

Sengé, P.M. 1990. 'The leader's new work: building learning organisations', Management Review, Vol. 32: 7-23.

Tjosvold, D. 1987. 'Participation: a close look at its dynamics', Journal of Management: 739-750.

Veldsman, T.H. 1991. Developing the 'learning organisation': eslablishing the prerequisites for flexible management. Paper presented at a conference entitled 'Flexible employer practices and multi-skilling'. 20 to 21 August 1991, Johannesburg: International Executive Communications.

Walton. R.E. \& Hackman, J.R. 1986. 'Groups under contrasting management strategies'. In Goodman. P.S. \& Associates. Designing effective work groups. San Francisco: Jossey-Bass, pp.168201.

Wellins, R.S., Bybam, W.C. \& Wilson, J.M. 1991. Empowered teams. San Francisco: Jossey-Bass. 